\title{
An Impirical Study on the Effect of Family Factor on Consumer Buying Behaviours
}

\author{
Assist. Prof. Dr. Durmaz Yakup \\ Faculty of Economics and Administrative Sciences \\ Gazikent University, Gaziantep, Turkey \\ E-mail: ydurmaz@adiyaman.edu.tr,yakupdu@hotmail.com
}

Zengin Sevil

Faculty of Economics and Administrative Sciences, Adiyaman University, Turkey

E-mail: sevil.zengin@yahoo.com

Received: April 14, 2011

doi:10.5539/ass.v7n10p53
Accepted: May 4, $2011 \quad$ Published: October 1, 2011

URL: http://dx.doi.org/10.5539/ass.v7n10p53

\begin{abstract}
Today's businesses are obliged to monitor and adapt themselves to the fast-evolving business environment not only to coordinate themselves with fierce competition and but also to survive. Businesses take modern approaches as a goal to have a voice in the management in the process which is continuously refreshing itself. Formerly, marketing concept worked in production-oriented; however, later on, it began to work in consumer-oriented.

Nowadays, consumer behaviouris influenced not only by consumer personalities and motivations, but also by the relationships within families. Family is a social group and it can be considered the cornerstone of consumers so it has a crucial place in the perception of marketing.

Marketeers closely interested in this issue to know the family which changed and renewed in course of time. It provides a tremendous advantage for a marketeer to know the family structure and its consumption characteristics.

In this study, how family factor affect consumer behaviors in Turkey with the participation of 1286 people in the provinces through interviews..
\end{abstract}

Keywords: Consumer, Consumer behaviour, Family structure, Tendency of consumption

\section{INTRODUCTION}

The success of a business in the market depends on not only the elements of marketing mix under the business control but also the variables beyond the conrol of environment. The majority of these environmental factors affect consumers and the marketing mix. The success of a business in large extent depends on whether the respond appropriately to changes in these environmental factors.

Experienced innovations in today's business world, have brought contemporary management approachs. These developments have changed focus of activities. If it is viewed from the perspective of contemporary management approachs, all activities of companies are seen to become people-oriented. There, the focus of marketing efforts are also consumers.

In 1970s, widespread contemporary (customer-oriented) marketing is focused on understanding the consumer. Considering this aspect of marketing activities, marketing is not completely about sales but customer-oriented marketing activities is become more important issue for marketers. For this reason business are required to analyze the size of their target group properly.

In this study, the concept of family, family household and non-household examined and how they influence consumer buying behaviour. 


\section{CONSUMER AND CONSUMER BEHAVIOUR}

Today's successful companies have one thing in common. Like Nike, their success comes from a strong customer focus and heavy commitment to marketing. These companies share an absolute dedication to sensing, serving and satisfying the needs of customers in well-defined target markets (Kotler, Wong, Saunders \& Armstrong, 2005: p. 40). Modern marketing through the wishes and desires of consumer can be define as the idea to produce goods and servicesin order to satisfy consumers and also taking into consideration the economis status of the target consumers of these products are produced in pricing and promotion therefore enriching after-sales warranty technical services to make a profit. As can be seen by the definition of modern marketing, the primary purpose of modern marketing is to satisfy consumer needs ( Durmaz, 2006: p. 2). First of all, the concept of consumer and customer should be define clearly. Despite the different names given to both of these concepts in English, in Turkish these two concepts are generally used interchangeably.

Consumer (User) can be define as the person or persons who want to have the goods and services or use them himselfso who actually use or consume the product.On the other hand, customer (Buyer) is the person who buy goods or services from a specific stores so who actually makes a purchase(Khan, 2006: p. 9).Consumer's curiosity create that why they buy something. These interests and motivations belong to the person, family or a business.

Consumer behavior is the study of how and why people consume products and services. All behavior can broadly be attributed to three classic influences - the particular characteristics of the individual, the environment that surrounds the individual, and the inherited genetics that constitute the biological makeup of the individual ( Chaudhuri, 2006: p. 18). Moreover, consumer buying behaviour can be define as the buying behaviour of final consumers - individuals and households who buy goods and services for personal consumption (Kotler, 2005: p. 255).

Furthermore, consumer behaviour works on why and how people consume the goods or services. It is a simple definition of consumer buying behaviour. It investigates behaviour which is earlier process of buying (prepurchase), the process of purchasing (purchase) and also next purchase after buying (postpurchase). Hence, consumer buying behaviour influenced by cultural, social, personal and psychological factors(Kotler, 2005: p. 136). Consider, for example, the act of buying a washing machine. Prior to the purchase, consumers may search for relevant information on the Web, consult friends and coworkers, read consumer magazines, and discuss the options with a spouse or partner. Th e information obtained may narrow the decision to a small number of manufacturers and brands. At this point, the consumer may well visit one or more local showrooms to view the diff erent brands and consult sales representatives about prices, warranty, installation, delivery times, removal of the existing washing machine, and so forth. Finally, the consumer decides on a particular brand and places an order(Haugtvedt, Herr \& Kardes, 2008: p. 525).

In addition, customer satisfaction is an important issue in order to understand customer behaviour. Customer satisfactionhas been the subject of considerable research, and has been defined and measured in many ways(Oliver, 1997: p. 36).

It may be defined as follows; customer satisfaction is the customer's fulfilment response to a consumption experience, or some part of it. Customer satisfaction is a pleasurable fulfilment response. Dissatisfaction is an unpleasurable fulfilment response. The 'experience, of some part of it' component of the definition allows the satisfaction evaluation to bedirected at any or all elements of the customer's experience. This can include product, service, process and any other components of the experience (Buttle, 2004: p. 21).

Everyone in business wants to interact positively with customers and clients. You want them to feel good about what you do and how you do it. You want that feeling to be so persuasively positive that the thought of doing business with you again isn't even a debatable point — of course they're going to come back! The same is true of your personal life. If you enjoy someone's company, you're naturally going to want to extend that relationship into the future(Berenbaum \& Larkin, 2007: p. 22).

\section{FAMILY FACTORS AFFECTING CONSUMER BEHAVIOR}

The trouble with the origin of the family is that no one really knows. Since Engels wrote The Origin of the Family, Private Property and the State in 1884, a great deal of new evidence has come in. Yet the gaps are stil enormous. It is not known when the family originated, although it was probably between two million and 100,000 years ago. It is not known whether it developed once or in seperate times and places(Gough, 1971: p. 760). Research on social behaviour of consumers shows that consumer socialization influences motivation, attitudes, and behaviours of adolescent(Carlson, Walsh, Laczniak \& Grossbart, 1994: p. 28). 
Consequently, compared with a few decades ago, many families are spending more money resulting in a change in the family communication structure. Many parents give their children an allowance as compensation for not being able to be with them all the time. That amount of money an adolescent can spend is increasing yearly (Chang, Liu \& Wen, 2008: p. 418).

Most people's idea of a normal household is of a married couple with children. However, in real life, the situation may be more complicated. For instance, in 2001, only 23 percent of British households consisted of a couple, married or unmarried, living with dependent children, as compared with 35 per cent in 1971. In 2001 considerably more households, 14 per cent, actually consisted of people living on their own (Social Trends, 2002: p. 40). Marriage used to be considered the cornerstone of family life but, in the year 2000, 67 per cent of respondents from the British Social Attitudes survey though that "it is all right for a couple tol ive together without intending to get married" (Fulcher \& Scott, 2003: p. 444). One might conclude from this that family life is in decline, and some have indeed reached this conclusion and argued that this decline is responsible for many of the ills of today's society.

A family is two or more people living together who are related by blood or marriage. It is a part of a household which consists of individuals living singly or together with others in a residential unit. Consumer behaviour is influenced not only by consumer personalities and motivations, but also by the relationships within families (family is a familiar social unit). In a family, members must satisfy their individual and shared needs by drawing on a common and shared, relatively fixed supply of sources. The individual family is a strong, most immediate and most pervasive influence on decision-making.

The husband, wife and children influence each other and are influenced by others. A consumer is influenced by many factors as shown below in figure 1: (Khan, 2006: p. 68).

The nuclear family which is the preferred social unit in a society, is itself an exclusive unit, its membership reserved to a married couple and their dependent children (nowadays, we may be take into consideration to pets as a nuclear family member). Exclusivity gives the family much of its moral power over the lives of its members, for it forges in them a sense of common destiny and mutual commitment (Barlett, 1984: p. 879). The extended family can be defined as an emphasis on family relationships and a strong value placed on childbearing as an integral part offamily life and the feminine gender role (Rafaelli, 2004: p. 287). The idea that extended families were a refugefor the poor in the nineteenth century is also widespread in the work of the first generation of quantitative social historians(Rugles, 2001: p. 26). Moreover, the extended familyoften described as the three generations live together in the same place. The extended family can be seen in the form of not only the grandmother or grandfather but also sometimes aunts, uncles even cousins. With the urbanization process, nuclear family has been switched to the right type of extended family. In our country, Turkey, nuclear and extended family can be seen at the same time. Commonly, the nuclear family can be seen in urban areas; on the other hand, the extended family can be seen in rural areas.

\subsection{Families Structure in Society}

Different countries which have various culture have own family institutions in their own society. Therefore, family structure and values of societies are also varying from society to society. In other words, the rules of the society learned in the family firstly. Also, human love, love of country, love of flag and religious values learned in the family firstly.

Regular societies formed by the regular presence of families so the families are really important for all societies. When families was establishing, the families are also required to comply with laws. For instance, According to Turkish law regulating the civil institution of marriage in our country, for at least 15 to marry women and men must be at least 17 years old. Marriages under the age of 18, there should be the parents' permission to marry (http://www.egzersiztr.com/aile-kavrami-ve-toplumdaki-yeri-onemi.html, 2010). Another provision in the Turkish civil law, close relatives and persons who have mentally ill can not get married.

The importance of the family in society should not be ignored. In western societies which did not enough attention to family structure faced with many social problems. In recent years, western socities recognized the situation and so they embraced the family institutions. Besides, at the moment, there is a strong family structure in Turkish society and The concept of family has always important place for Turkish society.

\subsubsection{European Socities}

While it might still be too early to draw definite conclusions, it's reasonable to speculate that historians will regard the period from the 1990 s to 2005 as one of the most politically, socially and economically turbulent time-frames in modern history. Radical political and market changes throughout Western and Eastern Europe are 
reflections and outcomes of intense social change in European societies that have been under way since the 1950 s.

Since 1960 the EU has seen a trend of falling numbers of marriages and an increase in the number of divorces. Moreover, people are remarrying more often than they did before the 1960s, and men are more likely to form a new family than women. Couples marry youngest in Portugal and oldest in Denmark, and the greatest age difference between husbands and wives is to be found in Greece.

There is a great deal of family diversity throughout Europe, and the conceptualization of family is based on ideology, popular mythology and conventions that are firmly rooted in each country's historical, political, economic and cultural traditions. Certainly, European governments have had a strong history of requiring regular and upto-date socio-demographic information on the behaviour of families (birth rates, fertilityrates, divorce rates), and about family forms (size, structure and organization). This sortof information is an essential component in governments' policy-making processes (Solomon, Bomossi, Askegaard \&Hogg, 2006: p. 403-406). As an example of the problems of comparing families across Europe, consider the problem of dealing with the age of children livingat home. In most EU member states, no age limit was applied during the 1991 census. However, in Denmark, Finland and Sweden, children were considered as part of the family up to the age of 18, and in Luxumbourg to 25. France applied a limit of 25 years until 1982, but this was abolished for the 1991 census, which increased the proportion of loneparent families by 35 per cent!

In Turkey, the situation is slightly different. With the age of the children living at home not be identified with any law, but the person who is 18 years old or higher has opportunity and possibility to make their own decisions and also if they want to live alone, it is possible for them. In real life, especially from east to west, the children left their home because they want to survive alone. This behavior has changed by family structure. Family structure has changed over time and these changes influence family consumption trends.

\subsection{Family Life Cycles (FLC)}

Families change over time, passing through a series of stages. This process is called the family life cycle (FLC). Although the concept has been used in the literature since 1931, it received its widest influence in marketing research by Wells and Gubar (wells and Gubar, 1996: p. 355). The FLC describes patterns found among families as they marry, have children, leave home, lose a spouse, and retire. Also, it can be recognized contemporary developments of divorce, smaller sizes of families, and delayed age of marriage (Murpy \& Staples, 1979: p. 12).

\section{APLICATION}

\subsection{Purpose and Scope of research}

The purpose of this study is by shedding light to the managers of founded and will be set up business and especially to the marketing department, which provides to development of country and which leads that the consumers are better known by them and better quality goods, services and ideas will be presented

In the 1950s, "contemporary (modern) marketing concept" expresses the consumer-oriented businesses. What, when, where and at what price and why wants consumers, these questions were asked firstly about forty years ago. In other words, get to know people has become more important.

\subsection{Methods and Sample}

In this study as data collection method questionnaire was preffered to obtain objective data and to interpret the first order, that person is the source or first hand. Questionnaire has been prepared according to the 'funnel'technique, that means from general to special. . Assumption of this technique, wenn the special questions are asked at first place to the surveys, they will be probably avoided.

Research data, by sampling the group of Gaziantep, Samsun, Sinop, Manisa, and Adiyaman provinces, consist of multiple choice questions for the questionnaire.

\subsection{Limiting of investigation}

In the survey, although mainly seven (7) regions in our country and each region sampling several cities by selecting the survey to be made target designation, the financial problems and the main mass of the width of the study limitations constituted.

\subsection{Results Analysis and Interpretation}

The data obtained were analyzed through computer program package "frequency" and the results were inerpreted according to this method.

1) The most important thing for me is "approval of my family" on the goods and sevices that I will take. 
The purpose of these question is to learn how important the family in buying goods and services of the survey participants.

As shownbelow in table 1 and figure 2; for 328 people $(\% 25,9)$ family is the most important criteria in buying goods and services, 560 people (\% 44.2) family is important criteria that, 266 persons ( $21 \%$ ) family is not important criteria that and that 92 people (\% 7.3) never family is not important criteria that. According to these results, it can be said that the majority did believe that the most important factor in buying goods and services are family.

2) You education level?

The purpose of this question is to learn education level of participant of this questionnaire.

As shownbelow in table 2 and figure 3; 655 people ( 51,3 percent) is high school graduates or equivalent, 313 people $(24,5$ percent $)$ is primary school graduates, 250 people (19,6 percent) is college graduates, 12 people $(0,9$ percent) has master degree.

3) You occupation?

The purpose of this question is to learn occupation status' of participants of this questionnaire.

As shownbelow in table 3 figure 4; 300 people $(23,5)$ people is self-employed, 243 people $(19,0$ percent) is worker, 183 people (14,3 percent) is officer, 97 people (7,6 percent) is unemployed, 87 people (6,8 percent) is teacher, 368 people $(28,8$ percent) has other professional.

4) In which group does your age take place?

The purpose of this question is to determine age of participants of this questionnaire.

As shown below in table 4 figure 5; 402 people ( 31,5 percent) is age between 18-25, 400 people ( 31,3 percent) is age between $25-35,333$ people $(26,1$ percent) is age between $35-45,106$ people $(8,3$ percent) is age between $45-55,34$ people ( 2,6 percent) is age above 55 . According to this result, most of the respondents are age between 18-35.

5) Marital status

The purpose of this question is to determine civil status' of participants of this questionnaire. As shown below in table 5 figure6;743 people (58,5 percent) is married, 495 people (39,1 percent) is single, 28 people is divorced widowed (who is again single after marriage for some reason). According to this result more than half of the respondents of this questionnaire is married people. (58,6 percent)

6) Gender

The purpose of this question is to determine the gender of participants of this questionnaire.

As shown below in table 6 figure7; 884 people (69,1 percent of participants of survey) is male, 393 people (30,7 percent) is female. According to the results, most of respondents of this questionnaire are male (70-6 percent).

\section{CONCLUSION}

Many people purchase as one person but actually there is more than one person behind the decision-making process. During the decision-making, buying process can be considered as more than one person in any stage of the evaluation phase. Also, in decision-making process, families and their structures need to be recognize and analyze deeply. Today, the concept of marketing is much more complicated.Along with the changing in social, economic and politic areas, human behaviour has changed at the same time and so existing marketing strategies must change according to these new situation. Today, the marketers have begun to implement more various marketing strategies. These reached results are important in terms of overall marketing policy and strategy as well as international marketing and a company's marketing and property policy.

As a result, a good marketer knows and needs to analyze very well all the factors that affect consumer behavior. If the marketers have good analysis of family structure, they also analyze the consumers. Factors that affecting consumers connected to each other like a chain; even a single factor can not be analyzed good enough that let an entire marketing strategy will be disrupted and so failure.

\section{References}

Aile Kavramı Ve Toplumdaki Yeri. $\quad$ [Online] Available: http://www.egzersiztr.com/aile-kavrami-ve-toplumdaki-yeri-onemi.html (09 -12 -2010). 
Barlett, K.T. (1984). Rethinking Parenthood As An Exclusive Status: The Need for Legal Alternatives When the Premise of the Nuclear Family Has Failed, p. 879.

Berenbaum, D., \& Larkın, T. (2007). How To Talk To Customers- Create A Great Impression Every Time With Magic. Jossey- Bass Published, San Francisco, p. 22.

Carlson L., Walsh, A., Laczniak, R. N., \& Grossbart, S. (1994). Family Communication Patterns and Marketplace Motivations, Attitudes and Behaviours of Children and Mothers. The Journal of Consumer Affairs, p. 28.

Chang, W.L., Liu, H.T., LIN, T., \& Wen, Y.S. (2008). Influence of Family Communication Stracture and Vanity Trait on Consumption Behavior: A Case Study Of Adolescent Students in Taiwan. Research Library, p. 418.

Chaudhur1, A. (2006). Emotion and Reason in Consumer Behaviour. Elsevier Butterworth-Heinemann Publications, Oxford, p. 18.

Durmaz, Y. Modern Pazarlamada Tüketici Memnuniyeti ve Evrensel Tüketci Haklarl. Yaşar Üniversitesi Yayını, [Online] Available: http://joy.yasar.edu.tr/makale/no3_vol1/08_durmaz.pdf, (April 11, 2011).

Francis Buttle, F. (2004). Customer Relationship Management- Concepts and Tools. Elsevier Butterworth-Heinemann Publications, Oxford, p. 21.

Fulcher, J., \& Scott, J. (2003). Sociology. Oxford University Press, the U.K., s. 444.

Gough, K. (1971). The Origin Of The Family. Journal of Marriage and family, November -1971, s. 760.

Haugtvedt, Herr, P., \& Kardes, F. (2008). Handbook of Consumer Psychology. Lawrence Erlbaum Associates, NewYork, p. 525.

Khan, M. (2006). Consumer Behaviour And Advertising Management. New Age Internatonal Publishers Ltd., New Delhi, p. 9.

Kotler, P., Wong, V., Saunders, J., \& Gary Armstrong, G. (2005). Principles Of Marketing. Pearson Education Limited, England, p. 40.

Murphy, P.E., \& Staples, W. (1979). A Modernized Family Life Cycle. Journal of Consumer Research, June, p. 12-22. http://dx.doi.org/10.1086/208744

Oliver, R. L. (1997). Satisfaction: A Behavioural Perspective on the Consumer. Singapore: McGraw-Hill International, p. 36.

Raffaelli, M. \& Ontai, L.L. (2004). Gender socialization in Latino/a families: Results from two retrospective studies. Sex Roles: A Journal of Research, 5 50, http://dx.doi.org/10.1023/B:SERS.0000018886.58945.06

Ruggles, S. (2001). Living Arrangements And Well-Being Of Older Persons In The Past. University of Minnesota, United States of America., p. 26

Solomon, M., Bamossy, G., Soren Askegaard, S., \& Hogg, M.K. (2006). Consumer Behaviour A European Perspective. Prentice-Hall Inc., New Jersey, U.S.A, p. 403- 406.

Wells, W.D., \& Gubar, G. (1996). The Life Cycle Concept. Journal of Marketing Research, November, p. 355-363.

Table 1. According to the importance of the family consumer rating distribution

\begin{tabular}{|l|l|l|l|}
\hline \multicolumn{2}{|c|}{ Respond ers } & $\begin{array}{l}\text { Valid } \\
\text { perce } \\
\text { ntage }\end{array}$ & $\begin{array}{l}\text { Cumulative } \\
\text { p ercentage }\end{array}$ \\
\hline I certainly agree & 328 & 25,9 & 25,9 \\
\hline I agree & 560 & 44,2 & 70,0 \\
\hline I dont agree & 266 & 21,0 & 91,0 \\
\hline $\begin{array}{l}\text { I certainly dont } \\
\text { agree }\end{array}$ & 92 & 7,3 & 98,3 \\
\hline No idea & 22 & 1,7 & 100,0 \\
\hline Summation & 1268 & 100,0 & \\
\hline Unanswered & 18 & & \\
\hline Overall & 1286 & & \\
\hline
\end{tabular}


Table 2. Education level

\begin{tabular}{|c|c|c|c|}
\hline & Resp ond ers & $\begin{array}{l}\text { Valid } \\
\text { p ercentage }\end{array}$ & $\begin{array}{l}\text { Cumulative } \\
\text { p ercentage }\end{array}$ \\
\hline İliterate & 46 & 3,6 & 3,6 \\
\hline Primary school & 313 & 24,5 & 28,1 \\
\hline High school & 655 & 51,3 & 79,5 \\
\hline $\begin{array}{l}\text { Ündergradute } \\
\text { ( Varational } \\
\text { school or Faculty) }\end{array}$ & 250 & 19,6 & 99,1 \\
\hline $\begin{array}{l}\text { P ostgradute } \\
\text { ( Master or } \\
\text { D octorate) }\end{array}$ & 12 &, 9 & 100,0 \\
\hline Summation & 1276 & 100,0 & \\
\hline Unanswered & 10 & & \\
\hline Overall & 1286 & 1286 & \\
\hline
\end{tabular}

Table 3. Occupation

\begin{tabular}{|c|c|c|c|}
\hline & Responders & $\begin{array}{l}\text { Valid } \\
\text { p ercentage }\end{array}$ & $\begin{array}{l}\text { Cumulative } \\
\text { percentage }\end{array}$ \\
\hline T eacher & 87 & 6,8 & 6,8 \\
\hline Officer & 183 & 14,3 & 21,1 \\
\hline W orker & 243 & 19,0 & 40,1 \\
\hline $\begin{array}{l}\text { Free } \\
\text { occupation }\end{array}$ & 300 & 23,5 & 63,6 \\
\hline unoccupation & 97 & 7,6 & 71,2 \\
\hline Other & 368 & 28,8 & 100 \\
\hline Unanswered & 8 & 100 & \\
\hline Overall & 1286 & 1286 & \\
\hline
\end{tabular}

Table 4. Age

\begin{tabular}{|l|l|l|l|}
\hline & Responder & $\begin{array}{l}\text { Valid } \\
\text { Percentage }\end{array}$ & $\begin{array}{l}\text { Cumulative } \\
\text { Percentage }\end{array}$ \\
\hline Between 18-25 & 402 & 31,5 & 31,5 \\
\hline Between 26-35 & 400 & 31,4 & 62,9 \\
\hline Between 36-45 & 333 & 26,1 & 89,0 \\
\hline Between 46-55 & 106 & 8,3 & 97,3 \\
\hline 56 and ab ove & 34 & 2,7 & 100,0 \\
\hline summation & 1286 & 100,0 & \\
\hline
\end{tabular}


Table 5. Marital status

\begin{tabular}{|l|l|l|l|}
\hline & Resp onders & $\begin{array}{l}\text { Valid } \\
\text { Percentage }\end{array}$ & $\begin{array}{l}\text { Cumulative } \\
\text { Percentage }\end{array}$ \\
\hline Single & 495 & 39,0 & 30,7 \\
\hline maried & 743 & 58,6 & 99,8 \\
\hline widow & 28 & 2,2 & 100,0 \\
\hline summation & 1286 & 100,0 & \\
\hline
\end{tabular}

Table 6. Gender

\begin{tabular}{|l|l|l|l|}
\hline & Resp onders & $\begin{array}{l}\text { Valid } \\
\text { Percentage }\end{array}$ & $\begin{array}{l}\text { Cumulative } \\
\text { Percentage }\end{array}$ \\
\hline Female & 393 & 30,7 & 30,7 \\
\hline Male & 884 & 69,1 & 99,8 \\
\hline Other & 2 &, 2 & 100,0 \\
\hline summation & 1269 & 100,0 & \\
\hline
\end{tabular}

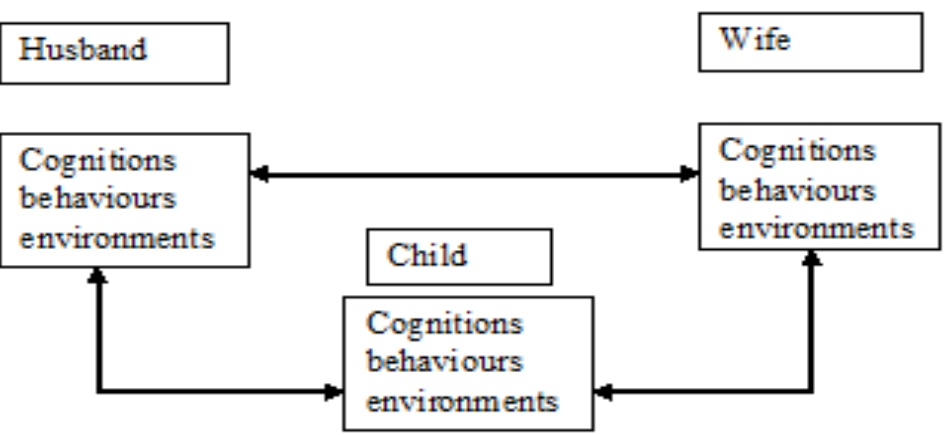

Figure 1. Family factors effecting consumer 


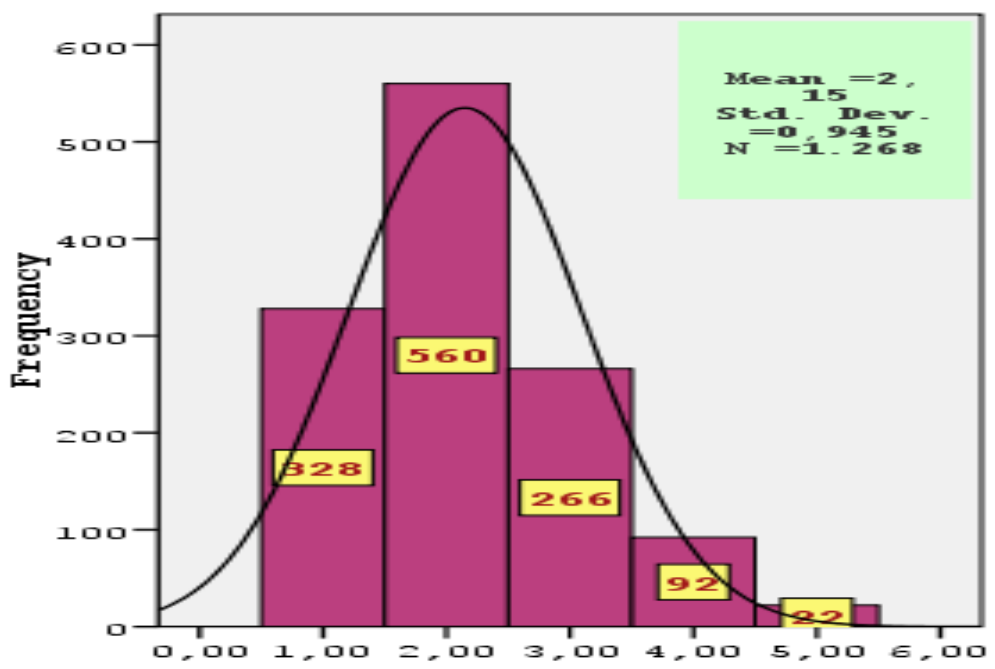

Figure 2. According to the importance of the family consumer rating distribution

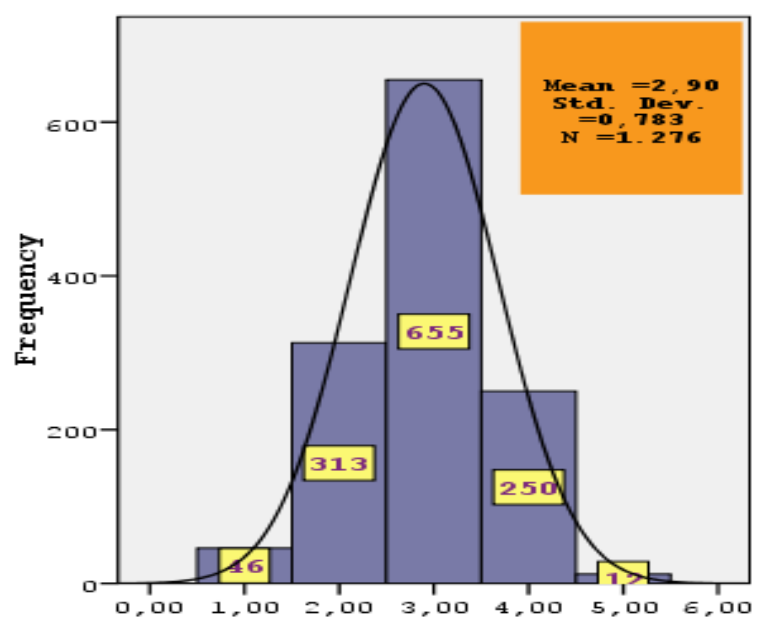

Figure 3. Education level

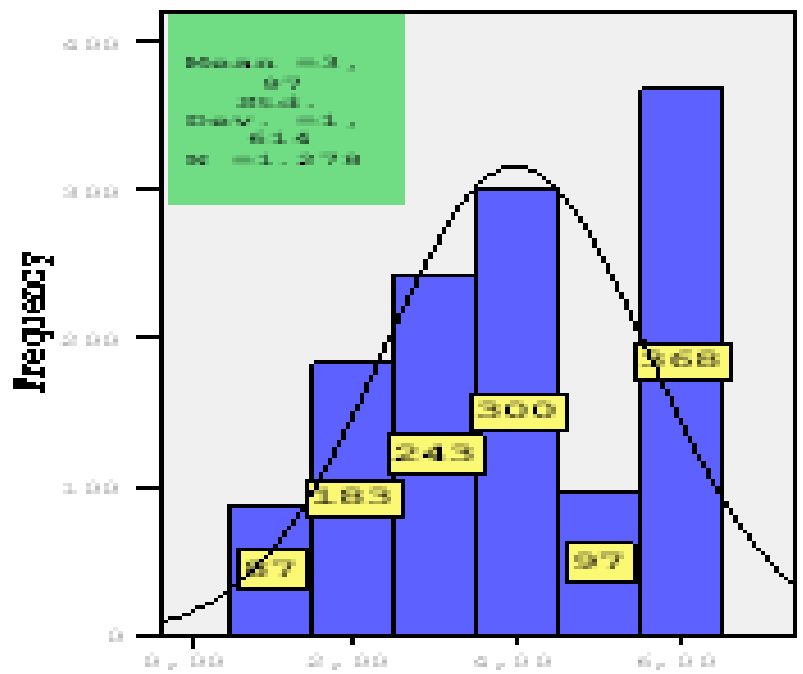

Figure 4. Occupation 


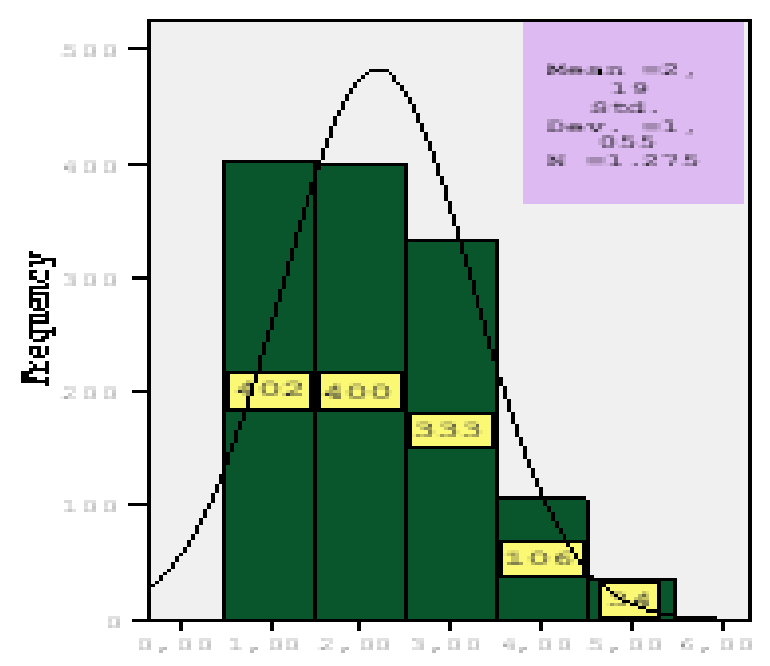

Figure 5. Age

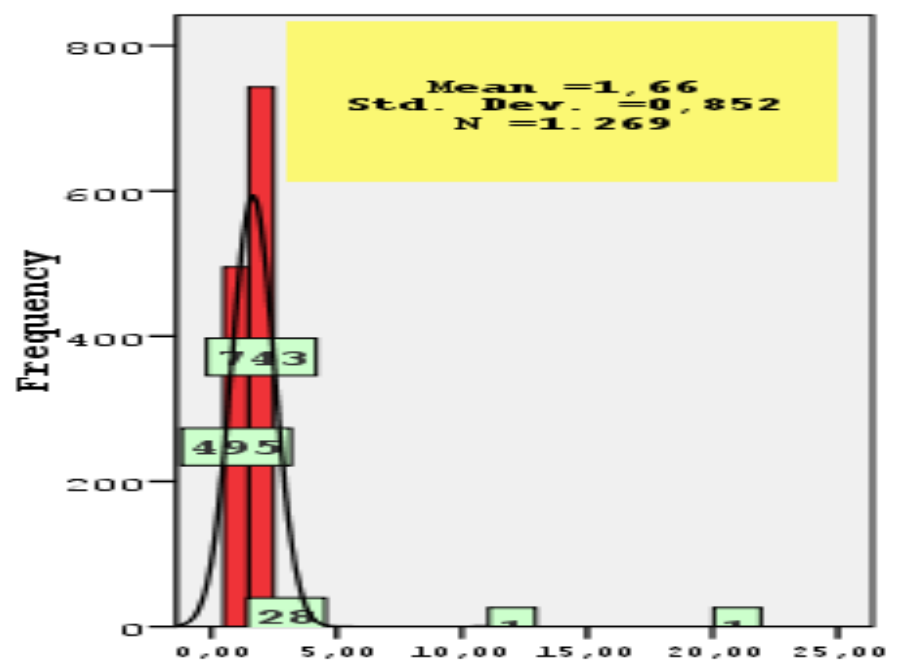

Figure 6. Marital status

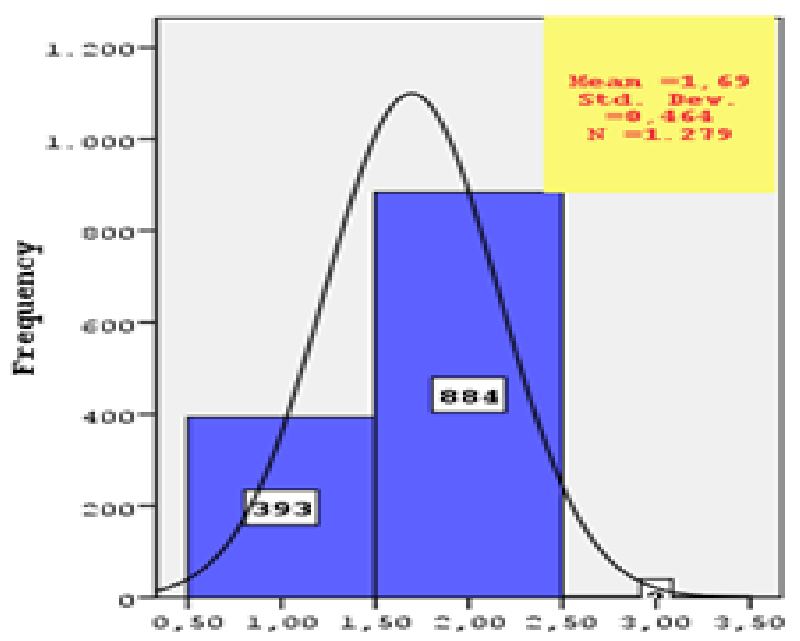

Figure 7. Gender 